\title{
LITERATURA
}

Bróż E., Podgórska M. \& PrZemyski A. 2006. The extinction of relict locations of Pleurospermum austriacum (L.) Hoffm. on the Małopolska Upland. - Nature Conservation 62(5): 43-57.

Celiński F., Rostański K., Sendek A., Wika S. \& CabaŁa S. 1978-1979. Nowe stanowiska rzadkich roślin naczyniowych na Górnym Śląsku i terenach przyległych. Cz. IV. - Zeszyty Przyrodnicze Opolskiego Towarzystwa Przyjaciół Nauk 18: 3-18.

IVERSEN J. 1954. The late-glacial flora of Denmark and its relation to climate and soil. - Danmarks Geologiske Undersøgelse, II Række 80: 87-119.

MAMAKOwa K. \& Środoń A. 1977. O pleniglacjalnej florze z Nowej Huty i osadach czwartorzędu doliny Wisły pod Krakowem. - Rocznik Polskiego Towarzystwa Geologicznego 46: 485-511.

MARKowski R. \& CHOJNACKI W. 1987. The biology of Pleurospermum austriacum (L.) Hoffm. in a relict locality of the Kashubian Lake District. - Acta Societatis Botanicorum Poloniae 56: 337-351.

Meusel H., JÄger E., Rauschert S. \& Weinert E. 1978. Vergleichende Chorologie der zentraleuropäischen Flora. 2, Text s. 418, Karten s. 171. Gustav Fischer Verlag, Jena.

MichaliK S. 1978. Rośliny naczyniowe Ojcowskiego Parku Narodowego. - Studia Naturae, Seria A 16: $1-171$.

RostAfiŃski J. 1872. Florae Polonicae Prodromus. Uebersicht der bis jetzt im Königreiche Polen beobachteten Phanerogamen. - Verhandlungen der kaiserlich-königlichen zoologisch-botanischen Gesellschaft in Wien 22: 81-208.

SzAFER W. 1930. Element górski we florze niżu polskiego. - Rozprawy Wydziału Matematyczno-Przyrodniczego, Polska Akademia Umiejętności 69, Seria 3, Dział B: 83-196.

Środoń A. 1970. Pleurospermum austriacum (L.) Hoffm. in the Quaternary of Poland. - Fragmenta Floristica et Geobotanica 16: 193-198.

ZAJĄC M. 1996. Mountain vascular plants in the Polish Lowlands. - Polish Botanical Studies 11: 1-92.

ZAJĄC M. \& ZAJĄC A. 2009. Elementy geograficzne rodzimej flory Polski. s. 94. Pracownia Chorologii Komputerowej, Instytut Botaniki, Uniwersytet Jagielloński, Kraków.

ZBigniew Szeląg, Instytut Biologii, Uniwersytet Pedagogiczny w Krakowie, ul. Podchorqżych 2, 30-084 Kraków, Polska; e-mail: azszelag@wp.pl

Wptynęto: 03.11.2019 r.; przyjęto do druku: 27.04.2020 r.

DOI: https://doi.org/10.35535/ffgp-2020-0048

\section{Występowanie Bupleurum rotundifolium (Apiaceae) na Wzgórzach Chęcińskich (Góry Świętokrzyskie)}

Bupleurum rotundifolium L. (przewiercień okragłolistny) jest jednym z najrzadszych archeofitów występujących w Polsce. Jego naturalny zasięg obejmuje południową Europę oraz południowo-zachodnią Azję. Ponadto rozprzestrzenił się na znacznych obszarach Europy (poza jej północnymi i północno-wschodnimi obszarami) na siedliskach segetalnych (Meusel i in. 1978; ZająC i in. 2009). 
W Polsce Bupleurum rotundifolium znany jest przede wszystkim z południowej części kraju. Najliczniej występował na Wyżynie Małopolskiej, Lubelszczyźnie oraz Wyżynie Śląsko-Krakowskiej. W Górach Świętokrzyskich, gdzie prowadzono badania, notowany był przede wszystkim na Wzgórzach Chęcińskich (na Grząbach Bolmińskich), Wzgórzach Kowalskich oraz wapiennych wzniesieniach w granicach Kielc. Obecnie potwierdzone stanowiska gatunku w kraju skupiają się na Wyżynie Małopolskiej: w Niecce Nidziańskiej, na Wyżynie Miechowskiej, Pogórzu Szydłowskim, Wzgórzach Chęcińskich oraz w Paśmie PrzedborskoMałogoskim (DOMINIAK \& MoćKo 1980; ZAJĄC \& ZAJĄC 2001; WĘGRZYNEK 2014).

Przewiercień okrągłolistny jest rośliną ciepłolubną i wapieniolubną, stąd też preferuje gleby rędzinowe. Występuje w zbiorowiskach kalcyfilnych chwastów upraw zbożowych z zespołu Caucalido-Scandicetum, dla którego jest gatunkiem charakterystycznym (MATUSZKIEWICZ 2008).

W następstwie modernizacji metod agrotechnicznych Bupleurum rotundifolium jest gatunkiem zagrożonym wyginięciem w Polsce (kategoria EN; ZAJĄC i in. 2009; WĘGRZYNEK 2014; KAŹMIERCZAKOWA i in. 2016). Gatunek wyginął już m.in. w Wielkopolsce i na Dolnym Śląsku (KĄCKI i in. 2003; JACKOWIAK i in. 2007), na Opolszczyźnie i Lubelszczyźnie jest krytycznie zagrożony (kategoria CR; NowAK i in. 2008; CWENER i in. 2016), a na Wyżynie Małopolskiej i w województwie śląskim uznany został za zagrożony wyginięciem (kategoria EN; Bróż \& PRZEMYski 2009; PARUSEL \& URbisz 2012).

Celem pracy jest przedstawienie aktualnych stanowisk, liczebności populacji Bupleurum rotundifolium oraz warunków siedliskowych w jakich rósł na Wzgórzach Chęcińskich.

Prezentowane dane są wynikiem badań fitogeograficznych prowadzonych w południowozachodniej części Gór Świętokrzyskich w latach 2010-2015 (uzupełnionych w latach 2016-2019). Dane o rozmieszczeniu gatunku zebrano zgodnie $\mathrm{z}$ metodą topogramu (FALIŃSKI 1990), a następnie stanowiska zlokalizowano w kwadratach o boku 2,5 km sieci ATPOL (ZAJĄC 1978).

\section{WYKAZ STANOWISK}

1. EE7231 - na północny-zachód od wsi Milechowy (Grząby Bolmińskie) ${ }^{1}$; uprawy zbożowe i odłogi na skalistych rędzinach jurajskich na południowym stoku (ok. 1000 osobników) i w części szczytowej Grząb Bolmińskich (ok. 300 osobników) - ostatnia obserwacja w 2019 r. Stanowisko stwierdzone również przez Bróża i Przemyskiego (npbl. 1992).

2. EE8201 - na południowy-wschód od osady Gajówka koło Milechowów; uprawy zbożowe i odłogi na skalistych rędzinach jurajskich na południowym stoku Grząb Bolmińskich, ok. 1000 osobników - ostatnia obserwacja w 2015 r.

3. EE8202 - na północny-wschód od kościoła we wsi Bolmin; uprawy zbożowe na skalistych rędzinach jurajskich na południowym stoku Grząb Bolmińskich, ok. 200 osobników - ostatnia obserwacja w 2015 r. Stanowisko stwierdzone również przez DoMINIAKA i MoćKĘ (1980).

\footnotetext{
${ }^{1}$ W Polskiej czerwonej księdze roślin (WĘGRZYNEK 2014) podano informację o występowaniu gatunku w rezerwacie Milechowy. W granicach rezerwatu brak jest jednak siedlisk segetalnych, przy czym występują one przy jego wschodniej granicy przy miejscowości Milechowy. Data ta jest prawdopodobnie wynikiem uogólnienia przy opisie lokalizacji.
} 
4. EE8411 - Wzgórza Kowalskie, na południe od wsi Bilcza-Podgórze (Bróż \& Przemyski npbl. 1992). Nie potwierdzono stanowiska w czasie badań.

W związku z głębokimi zmianami w sposobie użytkowania pól uprawnych i odejściem od tradycyjnego, ekstensywnego rolnictwa, Bupleurum rotundifolium jest silnie zagrożony na stwierdzonych stanowiskach. Grząby Bolmińskie na Wzgórzach Chęcińskich pozostają jednym z niewielu regionów, gdzie gatunek utrzymuje się jeszcze w uprawach zbożowych i na odłogach na silnie skalistych rędzinach, wykształconych na południowych stokach. Bardzo liczne populacje obserwowano przede wszystkim na okresowo odłogowanych polach i w uprawach zbożowych, gdzie nie stosowano herbicydów. Stanowiska ze Wzgórz Kowalskich (w okolicy wsi Kowala) nie zostały potwierdzone. Na obszarze tym powierzchnia zajmowana przez pola uprawne w ostatnich dekadach drastycznie zmniejszyła się w konsekwencji rozwoju osadnictwa. Ponadto część pól w okolicy Kowali przestała być użytkowana. Na wieloletnich odłogach, gdzie przemiany sukcesyjne są już zaawansowane, chwasty kalcyfilne ustępują bardziej konkurencyjnym gatunkom.

W celu ochrony gatunku należy promować tradycyjne metody uprawy na terenach, gdzie gatunek jeszcze występuje. Stwierdzone liczne populacje mogą stanowić rezerwuar diaspor dla odtworzenia stanowisk gatunku, jak i cennych zbiorowisk kalcyfilnych chwastów. Obecność na Grząbach Bolmińskich kilku innych, silnie zagrożonych archeofitów kalcyfilnych potwierdza, że obszar ten jest odpowiedni do przeprowadzenia programu ratowania archeofitów kalcyfilnych w regionie (ŁAZARSKI 2018 i cytowana tam literatura). Wskazana jest również ochrona $e x$-situ, np. w uprawach na terenie parków etnograficznych oraz zabezpieczenie materiału w banku nasion (ZAJĄC i in. 2009; WĘGRZYNEK 2014).

Summary. Occurrence of Bupleurum rotundifolium (Apiaceae) in the Chęciny Hills (Świętokrzyskie Mountains). Bupleurum rotundifolium is one of the rarest archaeophytes in Central Europe. In Poland it is considered an endangered species (EN category; ZAJĄC et al. 2009; WĘGRZYNEK 2014; KAŹMIERCZAKOWA et al. 2016) but in some regions it is already extinct (KACKI et al. 2003; JACKOWIAK et al. 2007) or critically endangered (CR category; NowAK et al. 2008; CWENER et al. 2016). The paper presents the current distribution, population size and habitat conditions of $B$. rotundifolium in the Chęciny Hills (southern Poland). The paper is based on floristic studies done during the vegetative seasons of 2010-2015 and supplemented in 2016-2019. The recorded localities were assigned to squares $(2.5 \times 2.5 \mathrm{~km})$ of the ATPOL grid system (ZAJAC 1978). During the study, three localities of the species were found in the vicinity of Bolmin and Milechowy villages. It grows in cereal crops and fallows on stony, Jurassic rendzinas on sunny slopes or at top of hills. The number of observed populations was estimated at hundreds or even thousands of individuals. The populations are threatened by intensification of agricultural practices. It is necessary to support traditional methods of cultivation on calcareous soils in areas where B. rotundifolium occurs (ZAJĄC et al. 2009; WĘGRZYNEK 2014).

\section{LITERATUTRA}

BRóż E. \& PrZEmyski A. 2009. The red list of vascular plants in the Wyżyna Małopolska Upland (S Poland). - W: Z. MireK \& A. Nikel (red.), Rare, relict and endangered plants and fungi in Poland, s. 123-136. W. Szafer Institute of Botany, Polish Academy of Sciences, Kraków.

Cwener A., Michalczuk W. \& KrawczyK R. 2016. Red list of vascular plants of the Lublin Region. - Annales Universitatis Mariae Curie-Skłodowska, Sectio C 71(1): 7-26.

DominiaK B. \& MoćKo E. 1980. Interesujące gatunki segetalne mezoregionu Góry Świętokrzyskie. - Studia Kieleckie 27(3): 33-35. 
FALIŃSKi J. B. 1990. Kartografia geobotaniczna 1. s. 284. Państwowe Przedsiębiorstwo Wydawnictw Kartograficznych, Warszawa - Wrocław.

Jackowiak B., Celka Z., Chmiel J., Latowski K. \& Żukowski W. 2007. Red list of vascular flora of Wielkopolska (Poland). - Biodiversity: Research and Conservation 5-8: 95-127.

Kaźmierczakowa R., Bloch-OrŁowska J., Celka Z., Cwener A., Dajdok Z., Michalska-Hejduk D., PAwlikowski P., SzCZEŚSIAK E. \& ZiaRneK K. 2016. Polska czerwona lista paprotników i roślin kwiatowych. s. 44. Instytut Ochrony Przyrody Polskiej Akademii Nauk, Kraków.

KĄCKI Z., DAJDOK Z. \& SzCZĘ́ŚNIAK E. 2003. Czerwona lista roślin naczyniowych Dolnego Śląska. - W: Z. KĄCKI (red.), Zagrożone gatunki flory naczyniowej Dolnego Śląska, s. 19-56. Instytut Biologii Roślin, Uniwersytet Wrocławski, Polskie Towarzystwo Przyjaciół Przyrody ,pro Natura”, Wrocław.

ŁAZARSKI G. 2018. Thymelaea passerina (Thymelaeaceae) - nowy archeofit Gór Świętokrzyskich. - Fragmenta Floristica et Geobotanica Polonica 25(2): 289-292.

Matuszkiewicz W. 2008. Przewodnik do oznaczania zbiorowisk roślinnych Polski. Vademecum Geobotanicum. 3. s. 537. Wydawnictwo Naukowe PWN, Warszawa.

Meusel H., Jäger E. J., Rauschert S. \& Weinert E. 1978. Vergleichende Chorologie der Zentraleuropäischen Flora. Bd. 2. Text \& Karten. s. 171. G. Fischer Verlag, Jena.

NowaK A., NowaK S. \& SpaŁeK K. 2008. Red List of vascular plants of Opole province. - Opole Scientific Society, Nature Journal 41: 141-158.

Parusel J. B. \& Urbisz A. (red.). 2012. Czerwona lista roślin naczyniowych województwa śląskiego. - Raporty Opinie 6(1): 105-177.

WęGRZYNEK B. 2014. EN Bupleurum rotundifolium L. Przewiercień okrągłolistny. - W: R. KAŹMIERCZAKOWA, K. ZARZYCKI \& Z. MireK (red.), Polska czerwona księga roślin. Paprotniki i rośliny naczyniowe, s. 354-356. Instytut Ochrony Przyrody PAN, Kraków.

ZAJĄC A. 1978. Założenia metodyczne „Atlasu rozmieszczenia roślin naczyniowych w Polsce”. - Wiadomości Botaniczne 22(3): 145-155.

ZAJĄC A. \& ZAJĄC M. (red.). 2001. Atlas rozmieszczenia roślin naczyniowych w Polsce. s. xii + 716. Nakładem Pracowni Chorologii Komputerowej Instytutu Botaniki Uniwersytetu Jagiellońskiego, Kraków.

ZAJĄC M., ZAJĄC A. \& TOKARSKA-GUZIK B. 2009. Extinct and endangered archaeophytes and the dynamics of their diversity in Poland. - Biodiversity: Research and Conservation 13: 17-24.

GRZEGORZ ŁAZARSKI, Wydziat Nauk Ścistych i Przyrodniczych, Uniwersytet PrzyrodniczoHumanistyczny w Siedlcach, ul. Prusa 14,08-110 Siedlce, Polska; e-mail: grzegorz.lazarski@ gmail.com

Wptynęto: 14.01.2020 r.; przyjęto do druku: 28.12.2020 r.

DOI: https://doi.org/10.35535/ffgp-2020-0049

\section{Preferencje żywicielskie Cuscuta lupuliformis (Convolvullaceae)}

\section{w Sandomierzu}

